\title{
Analysis on the Publicity and Education of "Chinese Dream" in College Students -----From the Perspective of Mental Health Education
}

\author{
Pei-Ling $\mathrm{LI}^{1}$ \\ ${ }^{1}$ China University of Geosciences, Beijing, China \\ lipeiling@cugb.edu.cn
}

Keywords: Chinese dream, Publicity and education approach, Psychological health education.

\begin{abstract}
At present, the academic research on "Chinese dream" into the ideological and political education of college students has become a hot spot . But few people are to explore the publicity and education of "Chinese dream" from the perspective of psychological health education which is an integral part of ideological and political education. This paper analyzes the current situation of the publicity and education of the "Chinese dream", explore the feasibility of the publicity and education of the "Chinese dream" from the perspective of psychological health education, and proposes three aspects to carry out the work.
\end{abstract}

\section{Introduction}

Xi Jinping, the General Secretary of China, pointed out: "realizing the Chinese dream of the great rejuvenation of the Chinese nation is to achieve national prosperity, national rejuvenation and the well-being of the people."at the First Session of the Twelfth National People's Congress on March 17, 2013. The Chinese dream is the combination of the basic principles of Marxism and Chinese contemporary reality, the common ideal of socialism with Chinese characteristics, and the new development of the socialist core value system. The propaganda and interpretation of the "Chinese dream" and the contemporary Chinese value sens should be combined closely. ${ }^{[1]}$ The propaganda and education of the "Chinese dream" from the perspective of mental health education are propitious to expand the propaganda way of the "Chinese dream", enhance college students' recognition of the "Chinese dream", mobilize the enthusiasm of college students to practice the socialist core values and enrich the practical exploration of the "Chinese dream".

The propaganda and education of the "Chinese dream" is generally carried out through the following ways, such as ideological and moral cultivation classroom, topics lecture, cultural activities on campus and the network propaganda and so on. These traditional ways may allow students to produce fatigue effect which is possible to hinder college students' recognition of the "Chinese dream". Obviously, it is particularly important to broaden the publicity and education of the "Chinese dream".

At present, colleges and universities have established the basic psychological counseling agencies. Mental health education of College Students is under the guidance of Deng Xiaoping Theory and the important thought of "Three Represents" and carried out according to the characteristics of physical and mental development of college students and educational laws with the aim of helping students achieve the goal of self growth, personality perfection, development potential, happy life. Therefore, taking the mental health education as the breakthrough point to carry out the propaganda and education of the "Chinese dream" is feasible .

\section{Exploration of the Publicity and Education of the "Chinese dream" from the Perspective of Psychological Health Education}

Teachers, students and teaching content are three important factors in the process of education. Among them, the students are the subject of study, the teachers play key roles in education, and the teaching content is the main information that teachers transfer to the students in the process of teaching and learning. To explore the publicity and education of the "Chinese dream" from the perspective of psychological health education mainly from three aspects: pivotal role of the 
psychology teachers, effective integration of positive psychology and "China dream" and subjectivity of students.

\section{Strengthening the Psychological Teachers' Correct Understanding of the "Chinese Dream" is the Key.}

Education is the interaction between teaching and learning, including the laws that how do teachers teach students in accordance with their rules and the regularities of students' learning. Teachers' psychological quality and professional quality influence the teaching effect directly. The teachers should strengthen their own ideological and theoretical training, understand the socialist core values fully, and strengthen the cognition of the "Chinese dream" in the education of the "Chinese dream" .

Researchers divided teachers' theoretical knowledge into two categories: One kind is the theory that is advocated which is easy to be realized and affected by the influence of new information, but can not have a direct impact on teaching behavior. The other kind is the theory which has an important effect on the teaching behavior directly. The second kind knowledge is not easy to be aware of and less susceptible to the effects of new information changes, but is more affected by the culture and habits of the impact. [2] The psychology teachers should transform the knowledge of the "Chinese dream" advocated into the "Chinese dream" theory that can be used.Psychological teachers should be advocated by the "Chinese dream" knowledge, into the "Chinese dream" theory which can be used, that is to say, it is the combination of our culture and habits which requires the teachers to understand the "Chinese dream".

\section{The Effective Integration of Positive Psychology and the "Chinese Dream" is the Key.}

\section{The Concept and Research Level of Positive Psychology}

Positive psychology is the view that Seligman made in 1998 as president of the American Psychological Association. It is advocated that psychology should start from the actual, potential and constructive power, virtue and kindness of the people and promote a positive and healthy attitude to people's many psychological phenomena to make interpretation,so that it can stimulate people's own intrinsic positive strength and excellent quality. And then improve the quality of the individual and the quality of life.[3]

\section{The Starting Point and Foothold of "Chinese Dream"}

Xi Jinping, the General secretary of China, pointed out: Our people love life, looking forward to have better education, more stable, more satisfied with the income, more reliable social security, higher levels of medical and health services, more comfortable living conditions and a more beautiful environment. We look forward to the children can grow better, work better and live better. People's yearning for a good and beautiful life is the goal for us to strive for." at the meeting with Chinese and foreign reporters during the two sessions in 2012. Obviously, the starting point and ending point of the "Chinese dream" is the well-being of all the people and the overall development of freedom.

\section{The Effective Integration of Positive Psychology and the "Chinese Dream"}

Positive psychology and the "Chinese dream" are both for people to get a better development, So it is feasible to combine the two. The Eighteenth National Congress of the Communist Party of China put forward the morality education as the fundamental task of Education clearly, which strengthen that improving the ideological and political work, focusing on humanistic care and psychological counseling and fostering self-esteem and confidence, rational and positive social mentality."[4] In the propaganda and education of the "Chinese dream", making full use of the viewpoint of positive psychology is beneficial to arouse the enthusiasm of university students and promote the overall development of the students. Is conducive to mobilize the enthusiasm of College students,To promote its overall development, Maslow once said that there is a need for self fulfillment in every person's heart. This need will inspire people inner positive energy and excellent 
quality, which are used by positive psychology to help ordinary people or dig with some talent people to maximize their potential, to have a happy life.

\section{Giving Full play to the Student's Subjectivity Combined with the Personal Dream is Difficult.}

The propaganda and education of "Chinese dream" must be based on the level and characteristics of College Students' psychological development. College students are in a rapidly maturing and not truly mature level In terms of the overall psychological development. College Students' self consciousness strengthens gradually but development is not mature and emotion increases rich but volatility bigger which make them accept new things easily lacking of ability to identify the authenticity. Abstract thinking develops rapidly but is easy with the subjective one-side and the level of will improves significantly but is unbalanced and unstable.

In the propaganda and education of "Chinese dream", we can better play the subjectivity of students according to the principle of preparation of teaching. At this level, the key to education is to create a pleasant atmosphere for education. In the mental health education of college students, we should make the students understand their happiness is closely related to the prosperity of the whole country and the revival of the Chinese nation and let the students fully understand the dream of an individual is under the guidance of the "Chinese dream", pursue self realization and clear personal ideal, target and blueprint. we should maintain the initiative of students through cooperative learning, discovering learning and other teaching methods so that they actively participate in learning activities.

\section{Conclusion and Prospect}

In short, the propaganda and education of the "Chinese dream" are important measures to strengthen the ideals and beliefs and to build a spiritual pillar. From the perspective of mental health education in Colleges and universities, the "Chinese dream" publicity and education activities can effectively help students to understand the significance of the "Chinese dream", the spiritual essence and practical requirements. It is conducive to college students in the "Chinese dream" in the struggle to achieve the "personal dream" better to expand the "Chinese dream" education and education approach. In this publicity and education process, the psychological teachers should strengthen their correct understanding of the "Chinese dream", make the positive psychological thought throughout the teaching content, and combine with "personal dreams in order to give full play to the subjectivity of the students.

\section{References}

[1] J.P. Xi, the Governance of China. Foreign Languages Press, Beijing,2014.

[2] Q. Chen, R.D. Liu, Contemporary educational psychology. Beijing Normal University press, Beijing,2007.

[3] X.P. Liu, Contemporary positive psychology. China Light Industry Press, Beijing,2010.

[4] G. Feng, Pay close attention to implementation and promote the implementation of "College Students' mental health promotion plan". School party building and Ideological Education, J.502(2015) 4-7. 